\title{
Pengaruh Kombinasi Terapi Murottal Al-Quran dengan Relaksasi Nafas Dalam Terhadap Penurunan Tingkat Kecemasan Pada Pasien Pre Operasi Bedah Umum di RSUD Provinsi NTB
}

\author{
Hardianto $^{1)}$, Lalu Sulaiman ${ }^{2}$, Muhammad Amrullah ${ }^{2 *}$ \\ Email: Aam.dais.ad@gmail.com \\ 1) Undergraduate Nursing Student of Health Science Faculty Qamarul Huda Badaruddin University Bagu \\ ${ }^{2)}$ Lecturers of Qamarul Huda Badaruddin University Bagu
}

\begin{abstract}
ABSTRAK
Kecemasan adalah situasi di mana seseorang merasa khawatir, cemas, bahkan takut seolah-olah sesuatu yang berdampak buruk akan terjadi padanya. Kecemasan terjadi pada banyak pasien sebelum operasi. Kombinasi antara terapi murottal Al-Qur'an dan relaksasi pernapasan dalam adalah salah satu jenis terapi non-farmakologis. Tujuan dari penelitian ini adalah untuk mengetahui pengaruh kombinasi ini pada penurunan tingkat kecemasan pada pasien pra operasi di Rumah Sakit Umum Pusat Provinsi Nusa Tenggara Barat (RSU-NTB). Penelitian ini termasuk penelitian Pra-Eksperimental dengan desain satu kelompok pretest-posttest dengan menggunakan purposive sampling. Sampel dalam penelitian ini adalah semua pasien pra operasi sebanyak 16 responden. Data dianalisis dengan uji-t berpasangan. Hasil analisis menunjukkan bahwa nilai t-hitung lebih besar dari t-tabel $(9,667>1,761)$. Ini berarti bahwa ada pengaruh yang signifikan dari perawatan ini untuk mengurangi tingkat kecemasan pada pasien sebelum operasi. Berdasarkan hasil penelitian direkomendasikan untuk menggunakan jenis perawatan ini dalam upaya untuk mengurangi anexity pasien pra operasi.
\end{abstract}

Kata kunci: Murottal Al-Qur'an dan Relaksasi Napas Dalam, Pra-operasi, Kecemasan.

\begin{abstract}
Anxiety is a situation where a person feels worried, anxious, even afraid as if something those had bad impact will be happened to him. Anxiety occurs in many patients before surgery. The combination between of murottal Al-Qur'an therapy and deep breathing relaxation is one type of non-pharmacological therapy. The aim of this study was to determine the effect of this combination on the decreasing anxiety levels in patients preoperative surgery in the Central General Hospital of West Nusa Tnggara Province ( RSU- NTB). This research is include of PreExperimental research with one group pretest-posttest design by using purposive sampling. The samples in this study were all preoperative patients as many as 16 respondents. Data is analyzed by paired $t$-test. The result of analysis shows that $t$-count value is greater than $t$-table (9.667> 1.761). It means that there is a significance influence of this treatrment to decrease the level of anxiety in patients preoperative surgery. Base on the result of the research is recomended to use this kind of treatment in effort to decrease preoperative patients anexity.
\end{abstract}

Keywords: Murottal Al-Qur'an and Deep Breath Relaxation, Pre-operation, Anxiety.

\section{A. LATAR BELAKANG}

Tindakan operasi atau pembedahan merupakan salah satu tindakan yang menakutkan bagi setiap orang, meskipun para dokter dan perawat sudah menjelaskan bagaimana dampak dan manfaat yang akan dialami dari tindakan pembedahan tersebut, namun kebanyan orang masih merasa khawatir dengan tindakan yang mungkin menakutkan bagi diri mereka karena berbagai alasan atau banyak hal sehingga rasa takut tersebut membuat dirinya merasa cemas[1].

Kecemasan adalah perasaan yang tidak menyenangkan atau ketakutan yang tidak jelas dan hebat. Hal ini terjadi sebagai reaksi terhadap 
sesuatu yang dialami oleh seseorang. Dampak terbesarnya sering terjadi penurunan kualitas hidup dan menghambat pemenuhan tugas-tugas sebagai reaksi terhadap sesuatu yang di alami oleh seseorang [2].

Kecemasan biasanya berhubungan dengan segala macam prosedur atau tindakan asing yang harus dijalani pasien dan juga ancaman terhadap keselamatan jiwa akibat prosedur atau tindakan pembedahan dan tindakan pembiusan. Pasien yang mengalami kecemasan menunjukan gejala mudah tersinggung, susah tidur, gelisah, lesu, mudah menangis dan tidur tidak nyenyak [3].

Menurut Willian dalam World Health Organization [4] menyatakan bahwa lebih dari 234 prosedur operasi besar dilakukan diseluruh dunia setiap tahunnya. Penelitian membuktikan di Negara berkembang tingkat kematian disebabkan karena operasi mayor adalah 5-10\%, dan tingkat kematian dikarenakan obat bius dilaporkan tinggi. Infeksi dan komplikasi pada pasca operasi lainnya juga menjadi perhatian diseluruh dunia [4]. Banyak sekali penyakit yang memerlukan tindakan pembedahan atau operasi. Misalnya saja penyakit usus buntu, hernia, tumor, patah tulang dan batu ginjal.

Dalam mengatasi gangguan mental yang dialami pasien pre operasi diperlukan suatu intervensi yang tepat. Salah satunya dengan melakukan kombinasi antara murottal kitab suci Al-Qur'an dan relaksasi nafas dalam pada pasien pre operasi. Dimana Terapi murratal adalah terapi dengan menggunakan bacaan Al-Qur'an yang merupakan terapi religi dimana seseorang diperdengarkan bacaan ayat-ayat Al-Qur'an selama beberapa menit atau beberapa jam sehingga memberikan dampak positif bagi tubuh seseorang.

Hasil penelitian yang telah dilakukan AlQadhii dalam Indriyani [5], bahwa ada pengaruh yang terjadi dari mendengarkan murattal AlQur'an yaitu berupa adanya perubahan arus listrik otot, perubahan daya tangkap kulit. Relaksasi nafas dalam adalah pernafasan abdomen dengan frekuensi lambat atau perlahan, berirama, dan nyaman yang dilakukan dengan memejamkan mata. Dengan menggunakan relaksasi nafas dalam pasien pre operasi akan mendapatkan perasaan yang tenang dan nyaman, melemaskan otot untuk menurunkan ketegangan dan kejenuhan sehingga mengurangi kecemasan [6].

Jumlah tindakan pembedahan di dunia sangat besar, hasil penelitian di 56 negara pada tahun 2004 diperkirakan jumlah tindakan pembedahan sekitar 234 juta per tahun, hampir dua kali lipat melebihi angka kelahiran pertahun. Study pada negara-negara industry, angka komplikasi tindakan pembedahan diperkirakan 3-16\% dengan kematian 0,4-0,8\%.

Studi di inggris mencatat dari 5940 kasus dalam tindakan pembedahan, 2217 adalah kasus salah sisi pada pembedahan dan 3723 kasus salah perawatan atau prosedur pembaedahan dalam 13 tahun. Data Research and Learning Servis (RLS) di Inggris pada periode Agustus 2007 sampai Agustus 2008, terdapat 26 kasus $(3,6 \%)$ salah pasien, 353 kasus $(48,6 \%)$ terjadi salah memberi tanda pada tindakan pembedahan [7].

Di Indonesia jumlah kasus pembedahan terjadi peningkatan dimana pada tahun 2000 sebesar 47,22 \%, tahun 2001 sebesar 45,19\%, tahun 2002 sebesar 47,13\%, tahun 2003 sebesar $46,87 \%$, tahun 2004 sebesar 53,22\%, tahun 2005 sebesar 51,59\%, tahun 2006 sebesar 53,68\%, dan pada tahun 2007 belum terdapat data yang signifikan [8].

Berdasarkan hasil wawancara dengan salah satu petugas kesehatan di bidang keperawatan RSUP NTB mengatakan bahwa ada sebagian pasien operasi yang mengalami penundaan jadwal operasi karena belum siap dan merasakan kecemasan dengan tindakan operasi tersebut berhubungan tindakan operasi baru pertama kali dialaminya, karena merasa takut dan menjadi cemas sehingga tekanan darahnya menjadi meningkat bahkan setelah tanda tangan untuk persetujuan melakukan operasi atau informed consent. Kecemasan tersebut disebabkan karena operasi merupakan pengalaman pertama yang mereka hadapi, dan tidak tahu bagaimana dengan proses sesudahnya yang akan mereka hadapi. 
Mereka mengatakan tidak pernah mendapatkan penyuluhan terkait dengan kebutuhan psikologinya, perwat hanya memberitahu dan menjelaskan tentang prosedur pembedahan yang akan mereka jalani dan hanya berfokus kepada penyembuhan fisiknya saja.

Berdasarkan data dari instalasi rekam medis RSUP NTB pada tahun 2016 jumlah pasien yang menjalani operasi berjumlah 4.107 kasus, dari kasus operasi bedah umum $672(16,4 \%)$ kasus, operasi obgyn $804(19,6 \%)$ kasus, operasi mata $398(9,7 \%)$ kasus, operasi THT $511(12,4 \%)$ kasus, operasi orthopedi $455(11,1 \%)$ kasus, operasi urologi $756(18,4 \%)$ kasus, operasi bedah gigi dan mulut $28(0,7 \%)$ kasus, operasi bedah syaraf $330(8,0 \%)$ kasus, operasi jantung 11 $(0,3 \%)$ kasus, dan operasi bedah pelastik 142 $(3,4 \%)$ kasus.

Pada tahun 2017 jumlah kasus operasi meningkat menjadi 6.551 kasus karena ada penambahan dua golongan operasi yaitu operasi bedah gigi dan mulut, dan operasi bedah anak, dari kasus operasi bedah umum mencapai 1.229 $(18,8 \%)$ kasus, operasi bedah gigi dan mulut 65 (1,0\%) kasus, operasi bedah pelastik 177 (2,7\%) kasus, operasi bedah syaraf $587(9,0 \%)$ kasus, operasi jantung $0(0 \%)$ kasus, operasi mata 451 (6,9\%) kasus, operasi obgyn 1.332 (20,3\%) kasus, operasi orthopedi 760 (11,6\%) kasus, operasi tht $600(9,1 \%)$ kasus, operasi urologi $1.144(17,5 \%)$ kasus, operasi bedah onkologi 167 $(2,5 \%)$ kasus, dan pada operasi bedah anak sebanyak $39(0,6 \%)$ kasus. [9]

Sedangkan pada tahun 2018 triwulan 1 terdapat juga penambahan satu golongan operasi yaitu operasi paru dan jumlah pasien operasi sebanyak 1.860 kasus, dimana jumlah pasien operasi bedah umum 339 (18,2\%) kasus, operasi bedah gigi dan mulut $17(0,9 \%)$ kasus, operasi bedah pelastik $62(3,3 \%)$ kasus, operasi bedah syaraf $152(8,2 \%)$ kasus, operasi jantung 2 $(0,1 \%)$ kasus, operasi mata $113(6,1 \%)$ kasus, operasi obgyn $347(18,6 \%)$ kasus, operasi orthopedi $180(9,7 \%)$ kasus, operasi tht 165 $(8,9 \%)$ kasus, operasi urologi $340(18,2 \%)$ kasus, operasi bedah onkologi 97 (5,2\%) kasus, operasi bedah anak $46(2,5 \%)$ kasus, dan pada operasi paru sebanyak $2(0,1 \%)$ kasus. [10]

Terapi religi dapat mempercepat penyembuhan, hal ini telah dibuktikan oleh berbagai ahli seperti yang telah dilakukan Ahmad Al Qhadhi, direktur utama Islamic Medicine Institute for Education and Research di Florida, Amerika Serikat. Dalam konferensi tahunan ke XVII Ikatan Dokter Amerika, wilayah missuori AS, Ahmad Al Qadhi melakukan presentasi tentang hasil penelitianya dengan tema pengaruh Al-Quran pada manusia dalam perspektif fisiologi dan psikologi. Hasil penelitian tersebut menunjukan hasil positif bahwa mendengarkan ayat suci Al-Quran memiliki pengaruh yang signifikan dalam menurunkan ketegangan urat saraf reflektif dan hasil ini tercatat dan terukur secara kuantitatif dan kualitatif oleh sebuah alat berbasis computer [5].

Menurut Virgianti Nur Faridah dalam penelitiannya tentang terapi murottal (AlQur'an) mampu menurunkan tingkat kecemasan pada pasien pre operasi lapratomi. Dan dari 32 responden yang diteliti, hasil penelitian menunjukkan pasien pre operasi lapratomi sebelum diberikan terapi murottal Al-Qur'an mengalami kecemasan sedang yaitu sebanyak 18 orang $(56,2 \%)$ dan kecemasan berat yaitu sebanyak 14 orang $(43,8 \%)$. Setelah diberikan terapi murottal Al-Qur'an di dapatkan sebagian besar $(65,6 \%)$ mengalami tingkat kecemasan ringan. Dan hasil uji statistic Wilcoxon didapatkan nilai $\mathrm{Z}=-5.185$ dan $\mathrm{P}=0,000$ artinya ada pengaruh pemberian terapi murottal AlQur'an terhadap tingkat kecemasan. Berdasarkan hasil penelitian bahwa lebih dari sebagian pasien pre operasi laparatomi setelah diberikan terapi murottal pasien tersebut dapat merasakan perbedaan antara sebelum dan sesudah pemberian terapi murottal (Al-Qur'an) pasien merasakan perasaan yang lebih nyaman dan tenang karena merasa semua penyakit pasti ada obatnya dan Allah SWT selalu melindungi dan memberikan kesembuhan [5].

Berdasarkan hasil penelitian tentang 
perbedaan tingkat efektivitas antara pemberian terapi musik dengan terapi pembacaan AlQur'an terhadap penurunan tingkat kecemasan pasien pre-operasi di Rumah Sakit Islam Pekajangan dapat ditarik simpulan: tingkat kecemasan antara sebelum dan sesudah terapi musik terdapat perbedaan yang signifikan, sehingga pemberian terapi musik efektif menurunkan tingkat kecemasan pasien, tingkat kecemasan antara sebelum dan sesudah terapi murotal terdapat perbedaan yang signifikan, sehingga pemberian terapi murotal efektif menurunkan tingkat kecemasan pasien, tingkat kecemasan antara sesudah mendapatkan terapi musik dan murotal terdapat perbedaan yang signifikan, sehingga pemberian terapi murotal lebih efektif menurunkan tingkat kecemasan pasien dibandingkan dengan terapi musik [5].

Pertama kali pada tahun 1970 seorang cardiologist Havard University yang bernama Herberet Benson menunjukkan perubahan pada dalam tubuh ketika relaksasi dilakukan pada tingkat yang dalam. Dimana dapat merubah termasuk menurunkan tekanan darah, heart rate, respiratory dan menurunkan tegangan otot, sedapat mungkin perasaan harus tenang dan terkontrol atau nyaman.

Saat menghadapi pembedahan, klien akan mengalami berbagai stresor, diantaranya yaitu rasa takut dan cemas. Kecemasan pada pasien pre operasi harus diatasi, penanganan kecemasan pada pasien pre operasi salah satunya dengan tindakan tehnik relaksasi nafas dalam. Penelitian ini bertujuan untuk mengetahui pengaruh relaksasi nafas dalam terhadap penurunan tingkat kecemasan pasien pre operasi di RSUD Kota Bekasi tahun 2013. Adapun metode penelitian ini menggunakan desain penelitian quasi eksperimen dengan pendekatan one group pretest-posttes. Jumlah sampel sebanyak 30 responden. Sampel yang digunakan yaitu pasien pre operasi yang mengalami kecemasan di RSUD Kota Bekasi 2013.Sebelum di berikannya relaksasi nafas dalam rata-rata tingkat kecemasan responden berada pada kategori cemas sedang dengan persentase $70 \%$, setelah diberikannya relaksasi nafas dalam rata-rata tingkat kecemasan responden berada pada kategori cemas ringan dengan persentase $70 \%$. Hasil uji statistik menunjukan nilai p-value pada penelitian adalah 0.00 lebih kecil dari nilai alpha (0.05), artinya ada pengaruh yang signifikan antara pemberian relaksasi nafas dalam terhadap penurunan tingkat kecemasan pasien pre operasi. Dari hasil tersebut dapat disimpulkan bahwa setelah dilakukannya relaksasi nafas dalam kecemasan pada pasien pre operasi mengalami penurunan [11].

Berdasarkan data-data yang peneliti temukan maka peneliti tertarik untuk menawarkan dan mencoba memberikan salah satu intervensi kepada pasien pre operasi yaitu dengan kombinasi terapi murottal Al-Qur'an dan relaksasi nafas dalam dengan melakukan penelitian di lapangan, dan seperti yang ditemukan di Rumah Sakit lainnya bahwa pelayanan spiritual seperti memberikan nasehat agama, membaca surat-surat tertentu dalam AlQur'an dan mendengarkan murottal Al-Qur'an untuk meningkatkan semangat hidup pasien, memodifikasi lingkungan yang aman dan nyaman bagi pasien untuk beribadah belum sepenuhnya di terapakan di rumah sakit, dan kebanyakan dari perawat hanya memperhatikan kondisi fisiknya saja. Sehingga hal ini menarik perhatian peneliti untuk melakukan penelitian mengenai "pengaruh kombinasi terapi murottal Al-Qur'an dan relaksasi nafas dalam terhadap penurunan tingkat kecemasan pada pasien pre operasi di RSUP NTB ”

\section{Tujuan Umum}

Mengetahui pengaruh kombinasi terapi murottal Al-Qur'an dan relaksasi nafas dalam terhadap penurunan tingkat kecemasan pada pasien pre operasi di RSUP NTB.

\section{Tujuan khusus}

a. Mengidentifikasi karakteristik pasien pre operasi di RSUP NTB.

b. Mengidentifikasi tingkat kecemasan pada pasien pre operasi sebelum diberikan 
kombinasi terapi murottal Al-Qur'an dan teknik relaksasi nafas dalam di ruang otak kokoq RSUP NTB.

c. Mengidentifikasi tingkat kecemasan pada pada pasien pre operasi setelah diberikan kombinasi terapi murottal Al-Qur'an dan relaksasi nafas dalam di ruang otak kokoq RSUP NTB.

d. Menganalisis hasil pengaruh kombinasi terapi murottal Al-Qur'an dan relaksasi nafas dalam terhadap penurunan tingkat kecemasan pada pasien pre operasi di ruang otak kokoq RSUP NTB.

\section{B. METODE PENELITIAN}

Desain penelitian yang digunakan dalam penelitian ini adalah penelitian Pre eksperimental dengan menggunakan pendekatan One Group Pre-Post test design, yaitu tidak ada kelompok pembanding (kontrol) akan tetapi peneliti melakukan observasi pertama (pre test) yang memungkinkan untuk menguji perubahan yang terjadi setelah adanya eksperimen.

Dalam penelitian ini peneliti melakukan pengukuran tingkat kecemasan sebelum meminta responden unutuk mendengarkan murottal Al-Qur'an dan melakukan relaksasi nafas dalam. Melakukan pengukuran tingkat kecemasan sesudah meminta responden untuk mendengarkan murottal Al-Qur'an dan melakukan relaksasi nafas dalam dan membandingkan hasil pengkuran tingkat kecemasan sebelum dan sesudah mendengarkan murottal Al-Qur'an dan melakukan relaksasi nafas dalam.

Populasi penelitian ini adalah seluruh pasien pasien pre operasi yang berada di ruang rawat inap Otak Kokoq RSUP NTB Tahun 2018. Sampel dalam penelitian ini adalah sebahagian dari pasient pasien pre operasi bedah umum yang mengalami kecemasan di ruang rawat inap Otak Kokoq RSUP NTB yang diambil secara purposive sampling yang berjumlah sebanyak 16 orang.

\section{HASIL DAN PEMBAHASAN}

\section{Hasil Penelitian}

Hasil penelitian yang di lakukan oleh peneliti selama 2 minggu terhitung mulai dari tanggal 13 Agustus 2018 s/d 26 Agustus 2018, terhadap 16 orang responden menunjukkan hasil:

a. Tingkat kecemasan responden pada pasien pre operasi sebelum melakukan kombinasi terapi murottal al-qur'an dengan relaksasi nafas dalam

Tabel 1. Distribusi Tingkat Kecemasan Responden Pada Pasien Pre Operasi Sebelum Melakukan Kombinasi Terapi Murottal Al-Qur'an Dengan Relaksasi Nafas Dalam.

\begin{tabular}{|c|c|c|c|}
\hline No & Tingkat kecemasan & Jumlah & Persentase \\
\hline 1 & Kecemasan ringan & 4 & $25 \%$ \\
\hline 2 & Kecemasan sedang & 9 & $56,3 \%$ \\
\hline 3 & Kecemasan berat & 3 & $18,7 \%$ \\
\hline 4 & $\begin{array}{c}\text { Tidak ada } \\
\text { kecemasan }\end{array}$ & 0 & $0 \%$ \\
\hline \multicolumn{2}{|r|}{ Jumlah } & 16 & $100 \%$ \\
\hline
\end{tabular}

Tabel 1 menunjukkan tingkat kecemasan pada pasien pre operasi sebelum melakukan terapi murottal Al-Qur'an dengan relaksasi nafas dalam yang tertinggi adalah kecemasan sedang sebanyak 9 responden $(56,3 \%)$, dan terendah adalah kecemasan berat 3 responden $(18,7 \%)$.

b. Tingkat kecemasan responden pada pasien pre operasi setelah melakukan kombinasi terapi murottal al-qur'an dengan relaksasi nafas dalam

Tabel 2. Distribusi Tingkat Kecemasan Responden Pada Pasien Pre Operasi Setelah Melakukan Kombinasi Terapi Murottal Al-Qur'an Dengan Relaksasi Nafas Dalam.

\begin{tabular}{|c|c|c|c|}
\hline No & Tingkat kecemasan & Jumlah & Persentase \\
\hline 1 & Kecemasan ringan & 7 & $43,8 \%$ \\
\hline 2 & Kecemasan sedang & 7 & $43,8 \%$ \\
\hline 3 & Kecemasan berat & 0 & $0 \%$ \\
\hline 4 & Tidak ada kecemasan & 2 & $12,4 \%$ \\
\hline \multicolumn{2}{c}{ Jumlah } & 16 & $100 \%$ \\
\hline
\end{tabular}

Tabel 2 diatas menunjukkan bahwa tingkat kecemasan pada pasien pre operasi setelah melakukan terapi murottal Al-Qur'an dengan 
relaksasi nafas dalam yang tertinggi yaitu kategori kecemasan ringan 7 responden $(43,8 \%)$ dan kecemasan sedang 7 responden $(43,8 \%)$, sedangkan terendah yaitu kategori tidak ada kecemasan 2 responden $(12,4 \%)$.

c. Pengaruh kombinasi pemberian terapi murottal al-qur'an dan relaksasi nafas dalam terhadap penurunan tingkat kecemasan

Tabel 3. Diatribusi Pengaruh Kombinasi Pemberian Terapi Murottal Al-Qur'an Dan Relaksasi Nafas Dalam Terhadap Penurunan Tingkat Kecemasan.

\begin{tabular}{|c|c|c|}
\hline \multirow{2}{*}{ No.Res } & \multicolumn{2}{|c|}{ Skor Kecemasan } \\
\cline { 2 - 3 } & Pre test & Post Test \\
\hline 1 & 11 & 5 \\
\hline 2 & 14 & 11 \\
\hline 3 & 22 & 16 \\
\hline 4 & 18 & 13 \\
\hline 5 & 30 & 25 \\
\hline 6 & 23 & 18 \\
\hline 7 & 15 & 13 \\
\hline 8 & 17 & 15 \\
\hline 9 & 16 & 13 \\
\hline 10 & 9 & 5 \\
\hline 11 & 28 & 26 \\
\hline 12 & 17 & 14 \\
\hline 13 & 29 & 26 \\
\hline 14 & 26 & 22 \\
\hline 15 & 16 & 12 \\
\hline 16 & 13 & 12 \\
\hline Mean & 19.0000 & 15.3750 \\
\hline SD & 6.55235 & 6.56125 \\
\hline Ting & & \\
\hline
\end{tabular}

Tingkat kecemasan:
$<6 \quad$ : Tidak ada kecemasan
6-14 : Kecemasan ringan
15-27 : Kecemasan sedang
$>27$ : Kecemasan berat

Skor Maximal HARS : 54

Skor Minimal HARS : 14

Hasil Tingkat kecemasan pada pasien pre operasi sebelum dan setelah dilakukan terapi kombinasi murottal Al-Qur'an dengan relaksasi nafas dalam. Dengan dengan menggunakan uji t berpasangan menunjukkan hasil sebagai berikut:

Tabel 4. Data Hasil Uji t-Test

\begin{tabular}{|c|c|c|}
\hline $\mathrm{T}$ & $\mathrm{df}$ & Sig. (2-tailed) \\
\hline $\begin{array}{c}\text { Mean } \\
\text { Upper }\end{array}$ & $\begin{array}{c}\text { Std. Deviation } \\
\text { Lower }\end{array}$ & $\begin{array}{c}\text { Std. Error Mean } \\
\text { Upper }\end{array}$ \\
\hline 9.667 & 15 & .000 \\
\hline
\end{tabular}

Berdasarkan hasil perhitungan SPSS diperoleh hasil t-hitung 9,667 yang dikonsultasikan dengan t-tabeldengan tingkat kemaknaan 0,05 dan $\mathrm{db}=15$ didapatkan hasil ttabel yaitu sebesar 1.761 atau t-hitung lebih besar dari t-tabel $(9,667>1.761)$ sehingga Ho ditolak dan Ha diterima, artinya ada pengaruh terapi murottal Al-Qur'an dan relaksasi nafas dalam terhadap penurunan tingkat kecemasan pada pasien pre operasi operasi bedah umum di Ruang Otak Kokoq RSUD Provinsi NTB.

\section{Pembahasan}

a. Tingkat kecemasan responden pada pasien pre operasi sebelum melakukan kombinasi terapi murottal al-qur'an dengan relaksasi nafas dalam

Kecemasan merupakan suatu kondisi kegelisahan mental, keperhatinan, ketakutan, firasat atau putus asa karena ancaman yang akan terjadi atau antisipasi yang tidak dapat diidentifikasi tergadap diri sendiri [12]. Kecemasan juga kekhawatiran pada sesuatu yang akan terjadi dengan penyebab yang tidak jelas dan dihubungkan dengan perasaan yang tidak menentu dan tidak berdaya.

Pratiwi [13] mengemukakan bahwa faktorfaktor yang dapat menyebabkan kecemasan adalah keadaan biologis, kemampuan beradaptasi/mempertahankan diri terhadap lingkungan yang di peroleh dari perkembangan dan pengalaman, serta adaptasi terhadap rangsangan, dan stressor atau situasi yang dihadapi. Sumber/stressor yang dapat menyebabkan kecemasan didapatkan dari lingkungan sosial. Lingkungan sosail mempunyai aturan-aturan, kebiasaan, hokumhukum yang berlaku di daerah tertentu. Hal inilah yang menyebabkan individu harus dapat menyesuaikan diri dengan lingkungan social yang ada.

Muttaqin \& Sari [14], mengemukakan bahwa faktor-faktor yang dapat menimbukan kecemasan pasien pre operasi adalah takut terhadap nyeri, menghadapi ruang operasi dengan alat-alat bedah yang lengkap, takut 
kematian, takut tentang ketidaktahuan, takut tentang deformitas dan ancaman lain terhadap citra tubuh. Selain itu pasien juga sering mengalami kecemasan lain seperti masalah finansial, tanggung jawab terhadap keluaga dan kewajiban pekerjaan atau ketakutan akan prognosa yang buruk dan ancaman ketidakmampuan permanen, akan memperberat ketegangan emosional yang sangat hebat yang diciptakan oleh proses pembedahan.

Berdasarkan Tabel 2 jumlah responden terbanyak adalah tingkat kecemasan sedang yaitu sebanyak 9 orang responden (56,3\%).Dampak yang ditimbulkan oleh kecemasan yang dirasakan oleh pasien berbeda-beda tergantung dari tingkat kecemasan yang dirasakam oleh pasien. Perbedaan respon yang diberikan terhadap kecemasan yang dirasakan oleh setiap pasien dipengaruhi oleh banyak faktor, diantaranya adalah faktor usia, pekerjaan dan pendidikan.Berdasarkan uraian hasil dan teori diatas dapat diketahui bahwa kecemasan yang dirasakan oleh pasien pre operasi terjadi karena berkurangnya kemampuan untuk melakukan aktifitas fisik yang diakibatkan oleh perubahan fungsi tubuh.

\section{b. Tingkat kecemasan pasien setelah diberikan terapi murottal al-qur'an dan relaksasi nafas dalam}

Menurut Stoney, C dalam Amni[1] bahwa pendekatan spiritual dalam hal ini memperdengarkan ayat-ayat Al-Qur'an pada saat memberikan asuhan keperawatan ternyata mampu menurunkan kecemasan pasien. Keyakinan yang kuat bahwa setiap penyakit ada obatnya dan Al-Qur'an sebagai Asy-Syifa (obat) adalah sumber pengobatan tertinggi dan paling diyakini sangat membantu dalam menurunkan kecemasan pasien. Selain itu Teknik relaksasi dapat digunakan untuk mengurangi stress dan efek-efek yang ditimbulkan, yang memungkinkan klien mengontrol seluruh tubuh untuk merespon ketegangan dan kecemasan [15].

Berdasarkan Tabel 2, dapat diketahui bahwa setelah dilakukan kombinasi terapi murottal Al-
Qur'an dan relaksasi nafas dalam dari 16 responden yang memiliki kecemasan tertinggi adalah kecemasan ringan yaitu sebanyak 7 orang responden $(43,8 \%)$ dan kecemasan sedang yaitu sebanyak 7 orang responden $(43,8 \%)$, sedangkan kecemasan yang paling sedikit yaitu tidak ada kecemasan 2 orang responden $(12,4 \%)$.

Pasien yang mengalami tingkat kecemasan sedang sebelum diberikan kombinasi terapi murottal Al-Qur'an dan relaksasi nafas dalam mengalami perubahan tingkat kecemasan menjadi tingkat ringan setelah diberikan kombinasi terapi murottal Al-Qur'an dan relaksasi nafas dalam.

Hal ini dapat dilihat dari hasil observasi yang dilakukan oleh peneliti pada pasien yang mengalami kecemasan sedang setelah diberikan kombinasi terapi murottal Al-Qur'an dan relaksasi nafas dalam, dimana pasien yang sebelumnya terlihat tegang, tidak dapat focus terhadap kegiatan yang sedang dilaksanakan, gelisah dan mudah terkejut menjadi lebih rileks dan santai. Hasil wawancara yang telah dilakukan oleh peneliti terhadap pasien juga diperoleh data yang sama, dimana pasien mengatakan setelah melakukan kombinasi terapi murottal Al-Qur'an dan relaksasi nafas dalam yang dirahkan oleh peneliti selama dilakukan penelitian pasien merasa lebih tenang dan nyaman. Rasa tenang dan nyaman yang dirasakan oleh pasien terlihat dari sikap dan prilaku yang ditunjukkan oleh pasien, yaitu pasien tampak tenang, otot tidak kaku, pandangan mata focus, tidak gelisah serta lebih banyak senyum.

\section{c. Analisa pengaruh kombinasi terapi murottal al-qur'an dan relaksasi nafas dalam terhadap penurunan tingkat kecemasan pada pasien pre operasi. \\ Tingkat kecemasan pada pasien pre operasi sebelum dan setelah melakukan kombinasi terapi murottal Al-Qur'an dan relaksasi nafas dalam, dan setelah dianalisa dengan menggunakan uji t- hitung sebesar 9,667 yang dikonsultasikan dengan t-tabeldengan tingkat kemaknaan 0,05 dan $\mathrm{db}=15$ didapatkan hasil t-tabel yaitu sebesar}


1.761 atau t-hitung lebih besar dari t-tabel (9,667>1.761) sehingga Ho ditolak dan $\mathrm{Ha}$ diterima, artinya ada pengaruh terapi murottal Al-Qur'an dan relaksasi nafas dalam terhadap penurunan tingkat kecemasan pada pasien pre operasi operasi bedah umum di Ruang Otak Kokoq RSUD Provinsi NTB.

Seperti yang diketahui bagi umat islam, AlQur'an adalah sumber pengobatan tertinggi dan paling diyakini bahwa Al-Qur' an adalah sebagai asy-Syifa (obat) kan konsep bahwa setiap penyakit ada obatnya. Selain itu relaksasi nafas dalam juga adalah salah satu cara untuk mendapatkan ketenangan dan menghilangkan rasa nyeri dan kecemasan yang dirasakan.

Kombinasi terapi murottal Al-Qur'an dan relaksasi nafas dalam yang diberikan oleh peneliti pada pasien yang mengalami tingkat kecemasan ringan, sedang, maupun berat menunjukkan adanya perubahan tingkat kecemasan. Data hasil wawancara bahwa pasien yang semula berada pada tingkat kecemasan sedang selalu merasa tidak tenang, pusing, cemas, kadang mengeluh nyeri dada. Pasien juga mengeluhkan rasa tidak nyaman pada daerah sekitar dada dan perut, rasa mual serta kaku pada otot belakang leher, terutama pada luka yang diderita pasien, tetapi setelah diberikan kombinasi terapi murottal Al-Qur'an dan relaksasi nafas dalam oleh peneliti di Ruang Otak Kokoq RSUD Provinsi NTB diproleh data bahwa pasien merasakan perubahan pada perasaannya dimana yang tadi merasa cemas dan tidak tenang perlahan mulai terlihat agak tenang terutama setelah pemberian kombinasi terapi murottal Al-Qur'an dan relaksasi nafas dalam. Selain itu juga pasien mengatakan sudah tidak lagi merasa nyeri dada tetapi masih merasa mual, sedangkan kekakuan pada otot-otot dan kegelisahan berkurang bahkan tidak lagi.

\section{KESIMPULAN}

Kombinasi terapi murottal Al-Qur'an dengan relaksasi nafas dalam yang diberikan pada pasien preoperatif dimana dalam penelitin ini menggunakan responden sebanyak 16 orang dengan tingkat kecemasan pasien sebelum dan setelah diberikan kombinasi terapi murottal AlQur'an dengan relaksasi nafas dalam memiliki perbedaan yang signifikan. Tingkat kecemasan pasien sebelum diberikan kombinasi terapi murottal Al-Qur' an dengan relaksasi nafas dalam menunjukkan sebagian besar pasien berada pada tingkat kecemasan sedang sebanyak 9 responden, berat 3 responden dan ringan 4 orang responden.

Setelah diberikan kombinasi terapi murottal Al-Qur'an dengan relaksasi nafas dalam, tingkat kecemasan pasien preoperatif berada pada tingkat kecemasan ringan yaitu sebanyak 7 responden, kecemasan sedang sebanyak 7 responden dan tidak terdapat kecemasan berat. Artinya ada perubahan tingkat kecemasan pada pasien preoperatif setelah diberikan kombinasi terapi murottal Al-Qur'an dengan relaksasi nafas dalam. Yang mana dalam penelitian ini menunjukkan perubahan tingkat kecemasan yang positif sehingga dapat di simpulkan bahwa pemberian terapi kombinasi murottal Al-Qur'an dengan relaksasi nafas dalam dapat menurunkan tingkat kecemasan pada pasien preoperatif.

\section{DAFTAR PUSTAKA}

[1] Amni, H. (2014). Pengaruh Terapi Membaca Al-Qur'an Terhadap Penurunan Tingkat Kecemasan Pada Pasien Preoperasi Bedah Umum Di Ruang Seruni RSUP NTB. Skripsi, S-1 Keperawatan STIKES QH BAGU

[2] Nugroho W. (2008). Keperawatan Gerontik \& Geriatri Edisi 3. Jakarta: EGC

[3] Majid, Abdul dkk. (2011). Keperawatan Perioperatif. Yogyakarta : Gosyen Publishing.

[4] WHO. Guidelines on Hand Hygiene in Health Care. Library Cataloguing-inPublication Data; (2009).

[5] Firman. F. (2012). Efektivitas Terapi Murotal dan Terapi Musik Klasik terhadap Penurunan Tingkat Kecemasan Pasien Pra Operasi di Pekalongan

[6] Brunner dan Suddarth. (2001). Buku Ajar Keperawatan Medikal Bedah. Jakarta : EGC. 
[7] Panesar PS, Kumar R, Marwaha SS, Joshi VK (2009). Vermouth Production Technology-An overview. Natural Product Radiance, 8(4):334-344.

[8] Grace, Pierce A, neil R. Borley. (2007). At a Glance Ilmu Bedah. Edisi ketiga.Jakarta: Erlangga.

[9] Data Instalasi Rekam Medik Rumah Sakit Umum Provinsi NTB. (2017)

[10] Data Instalasi Rekam Medis Rumah Sakit Umum Provinsi NTB. (2018)

[11] Nurty. K. Gea, (2013). Pengaruh Relaksasi Nafas Dalam Terhadap Penurunan Tingkat Kecemasan Pasien Pre- Operasi Di RSUD Kota Bekasi Tahun 2013.

[12] Kozier. (2010). Buku Ajar Praktik Keperawatan Klinis. Edisi 5. Jakarta : EGC

[13] Pratiwi, Asih. (2010). Perilaku Prososial ditinjau dari Empati dan Kematangan Emosi. Jurnal Psikologi, Volume I, No 1. Kudus: Universitas Muria Kudus.

[14] Muttaqin, dkk. (2009). Asuhan keperawatan perioperatife: Konsep, Proses dan Aplikasi. Jakarta : Salemba Medika.

[15] Smeltzer, Suzanne C. dan Bare, Brenda G, (2002), Buku Ajar Keperawatan Medikal Bedah 